\title{
Students' Perception toward the Integrated Content-Based Reading Instructional Material
}

\author{
Syarif Amin ${ }^{1}$, Kisman Salija ${ }^{2}$ and Muhammad Basri ${ }^{3}$ \\ ${ }^{1}$ Universitas Negeri Makassar \\ Jalan Andi Pangerang Pettarani, South Sulawesi, Indonesia. \\ Email: syarifamin85 [AT] yahoo.co.id \\ ${ }^{2}$ Universitas Negeri Makassar \\ Jalan Andi Pangerang Pettarani, South Sulawesi, Indonesia. \\ Email: kismansalija [AT] unm.ac.id \\ ${ }^{3}$ Universitas Negeri Makassar \\ Jalan Andi Pangerang Pettarani, South Sulawesi, Indonesia. \\ Email: muhammadbasri [AT] unm.ac.id
}

\begin{abstract}
This study aims at developing reading instructional material using content-based instruction (CBI) approaches for the students of Islamic Education Department in a private university in Kendari, Southeast Sulawesi province, Indonesia. This is a research and developmental research with ADDIE developmental model. This study involved the lecturers and students of Islamic Education Department. This paper presents the students' perception toward the Integrated Content-Based Reading Instructional Material that had been designed. The result of this study found that the students of Islamic education department have a very positive perception toward the Integrated Content-Based Reading Instructional Material.
\end{abstract}

Keywords-Integrated Content-based Instruction (CBI), Reading instructional materials

\section{INTRODUCTION}

Integrating language teaching with subject teaching is an important thing to implement, specially in non-English majors, such as majors in economics, law, engineering, health, and others. Integrating language teaching with subject teaching improves the students' ability in English and increases their knowledge regarding the scientific field they are involved in.

One of the teaching approaches that integrate language teaching and subject teaching is the CBI approach. Leaver and Stryker (1989), as cited by Amiri and Fatemi (2014), state that CBI is an instructional approach in which "language proficiency is achieved by shifting the focus of the course from the learning of language per se to the learning of subject matter"(p. 2158) It is a model of teaching that simultaneously integrates language teaching and academic content (Brinton, Snow, \&Wesche,2003 cited in Butler, 2005; see also Madrid and Sanches, 2001; Dupuy, 2000; Suraya et al., 2018; Lai and Asornjarung, 2017; Tarnopolsky, 2013). It is "a subdivision of and rooted on principle CLT"(Shabani and Ghasemi, 2014; Villalobos, 2014).

One of the facilities that can support the effectiveness of the CBI approach in learning English in the classroom is the availability of a textbook that is suitable with the interests and needs of students. Hutchinson (1987) states that textbooks are not just a medium for daily learning activities that take place between teachers and students in the class, but they are also an embodiment of goals, values, and methods of certain teaching and learning situations. (Syaifullah, 2014)

Most universities or colleges in Indonesia design their own books for their students because they think the published books do not meet the needs of their students. The reason is that the published books do not fit the particular teaching context. Therefore, the lecturers are assigned to design their own books, which are in accordance with the student's learning needs (Syaifulloh, p.237).

This paper presents the students' perceptions toward the Integrated Content-Based Reading instructional material that had been designed by the researchers. This research is expected to provide practical benefits, especially in the field of English language teaching for Islamic studies. This research is expected to be able to produce products that can be used in the process of learning English in the Department of Islamic education especially at the university where this study conducted. 


\section{Objectives of the Research}

The objectives of this research were to find out the students' perception toward the Integrated Content-Based Reading Instructional Material developed by the researchers at the Islamic Education Department in a private university in Kendari, Indonesia.

\section{Significance of the Research}

This research is expected to provide practical benefits, especially in the field of English language teaching for Islamic studies. This research is expected to be able to produce products that can be used in the process of learning English in the Department of Islamic education. This is also expected to be a guideline for lecturers in designing and developing reading teaching material, not only for the lecturers who teach in Islamic Education majors, but also in other Islamicbased departments. For students, it is expected that this research can produce teaching materials that are in accordance with the needs of students so that they can feel a pleasant learning atmosphere. This research is also expected to provide benefits to policymakers as a reference in formulating the direction of the English language teaching curriculum.

\section{Previous Related Findings}

Researches related to the implementation of Content-Based Instruction (CBI) especially in the context of teaching English as a foreign language in Indonesia has been carried out by several researchers. Thamrin (2013) conducted R\&D a research to develop instructional model of content area reading to increase the students' effective reading ability at the State Polytechnic of Ujung Pandang. The result of his research proved that the model was effective in improving the students reading ability. The specific characteristic of that effective model include: 1) facilitating comprehension, 2) purposeful, 3) efficient, 4) effective, 5) relevant. Aisyah (2017) conducted a study on the effectiveness of Content-Based Instruction to teach speaking viewed from students' creativity. The study used an experimental research method with a total sample of 80 third-semester students from one of the Islamic universities in Indonesia. The results of the study indicated that the Content-Based Instruction approach is an effective method used in speaking instruction. The effectiveness of the method was influenced by the students' creativity.

The study also reported that there was an interaction between teaching methods and students' creativity in teaching speaking. Tsai and Shang (2010) conducted research about the impact of Content-Based Instruction on EFL Students' Reading Performance. The results of the study indicated that the utilization of content-based language instruction in the literature class could enhance students' reading comprehension as well as critical thinking ability. In contrast to some of the results of the research above, in this study, the researcher tried to elaborate on the students' perceptions of the integrated content-based reading instructional material that had previously been designed by the researcher.

\section{Content-Based Instruction (CBI)}

\section{a. The history of CBI}

Canadian experiments in the form of the French immersion education program at St.Limber are often linked to as the forerunner to the birth of the CBI. (see O'Maggio-Hadley, 2001; Swain and Johnson, 1997; Lambert and Tucker, 1972 cited in Cammarata, 2014;).

Immersion program held for post-secondary levels takes place at the University of California, Los Angeles, and the Monterey Institute of International Studies in California together with the British Columbia University and the University of Ottawa in Canada (Brinton \& Snow, 2017). Bernard Mohan published the first article related to CBI in 1986 with the volume title "Language and Content"(Brinton \& Snow, 2017) which in the introductory part of the article Mohan reveals a paradox"In subject learning we overlook the role of language as a medium of instruction. In the language learning we overlook the fact that content is being communicated"(Brinton \& Snow, 2017, p. 3).Integrating language teaching and subject teaching in an approach called Content-Based Instruction (CBI) is an attempt to eliminate this paradox(Lambert and Tucker, 1972 cited in Brinton \& Snow, 2017).

In the early 1980s learning models that integrated language teaching and subject teaching became an increasingly growing trend in the field of language teaching. This can be seen from the continued development of various models, programs, and approaches that integrate language teaching and subject teaching even though using different terminology (Myriam Met, 1999).

According to (Krueger and Ryan, 1993) as cited in(Brinton and Snow, (2017), "by the late 1980s, the modern language teaching community in the U.S. also began to apply CBI principles to "disciplined-based" approaches. Foreign languages across the curriculum programs sprang up at such places as St. Olaf College (Minnesota), the University of Minnesota, Eastern Michigan University, Earlham College (Indiana), and the University of Rhode Island"

Leaver and Stryker (1989) as cited by Amiri and Fatemi, (2014) state that CBI is an instructional approach in which "language proficiency is achieved by shifting the focus of the course from the learning of language per se to the learning of subject matter"(p. 2158) It is a model of teaching that simultaneously integrates language teaching and academic 
content (Brinton, Snow, \&Wesche,2003 cited in Butler, 2005; see also Madrid and Sanches, 2001; Dupuy, 2000; Suraya et al., 2018; Lai and Asornjarung, 2017; Tarnopolsky, 2013). It is "a subdivision of and rooted on the principle CLT'(Shabani and Ghasemi, 2014; Villalobos, 2014).

Snow (2014) as quoted by Brinton \& Snow, (2017) defines Content Based Instruction as “An umbrella term for a multifaceted approach to SFL teaching that differs in terms of factors such as educational setting, program objectives, and target population but shares a common point of departure the integration of language teaching aims with content instruction"

Duenas, (2004)states that CBI is a form of evolution of the Communicative Languages Teaching (CLT) approach which has the same principles as CLT. So it can be said that CBI is not a new teaching paradigm that is revolutionary. Although both depart from the same basic principles, CBI has its own peculiarities by making the subject as a means of teaching a second language or a foreign language.

CBI offers a concept of language teaching that considers the original nature of language. Not only seeing language as a mere activity of teaching the structure of language, but more than that it must be directed at teaching language as a communication tool (Bolanos, 2013). By placing students in an authentic and meaningful academic situation CBI can improve students' language skills without ignoring an increase in knowledge of academic content (Butler, 2005).

In CBI approach, "language is not merely the object of learning, but also the means for negotiating meaning, organizing information, and acquiring content knowledge" (Butler, 2005). It is an approach that presents a meaningful and tangible teaching contexts with authentic material through which the learner learns the language in its position as a means of learning content. (Abdul Karim and Mohammad Mosiur Rahman, 2016; Bolanos, 2013; Mustofa Amiri and Azar Hosseini Fatemi, 2014; Tseng, 2015)

\section{The Nature of CBI}

Leaver and Stryker (1989) as cited by Amiri and Fatemi, (2014) state that CBI is an instructional approach in which "language proficiency is achieved by shifting the focus of the course from the learning of language per se to the learning of subject matter"(p. 2158) It is a model of teaching that simultaneously integrates language teaching and academic content (Brinton, Snow, \&Wesche,2003 cited in Butler, 2005; see also Madrid and Sanches, 2001; Dupuy, 2000; Suraya et al., 2018; Lai and Asornjarung, 2017; Tarnopolsky, 2013). It is "a subdivision of and rooted on the principle CLT'(Shabani and Ghasemi, 2014; Villalobos, 2014).

Snow (2014) as quoted by Brinton \& Snow, (2017) defines Content Based Instruction as "An umbrella term for a multifaceted approach to SFL teaching that differs in terms of factors such as educational setting, program objectives, and target population but shares a common point of departure the integration of language teaching aims with content instruction"

Duenas, (2004)states that CBI is a form of evolution of the Communicative Languages Teaching (CLT) approach which has the same principles as CLT. So it can be said that CBI is not a new teaching paradigm that is revolutionary. Although both depart from the same basic principles, CBI has its own peculiarities by making the subject as a means of teaching a second language or a foreign language.

CBI offers a concept of language teaching that considers the original nature of language. Not only seeing language as a mere activity of teaching the structure of language, but more than that it must be directed at teaching language as a communication tool (Bolanos, 2013). By placing students in an authentic and meaningful academic situation CBI can improve students' language skills without ignoring an increase in knowledge of academic content (Butler, 2005).

In CBI approach, "language is not merely the object of learning, but also the means for negotiating meaning, organizing information, and acquiring content knowledge" (Butler, 2005). It is an approach that presents a meaningful and tangible teaching contexts with authentic material through which the learner learns the language in its position as a means of learning content. (Abdul Karim and Mohammad Mosiur Rahman, 2016; Bolanos, 2013; Mustofa Amiri and Azar Hosseini Fatemi, 2014; Tseng, 2015)

As a content-centered EFL teaching approach (Peng, 2017)CBI aims to develop the learners' communicative competence in the target language while developing knowledge in certain scientific subjects (Oxford, 1993) It provides opportunities for students to choose the desired material and also focuses on improving students' language skills (Yugandhar, 2016) It can be a solution for learners of advanced English because in the CBI content is taught in the target language so that learners get two knowledge at once namely language knowledge and content knowledge (Dupuy, 2000).

The principle underlying CBI is that target language teaching material presented in a meaningful manner, with a contextual approach, and focusing on acquiring information and knowledge will make it easier for students to succeed in learning. In this case, the content or particular subject is the organizing principle, and other basic aspects such as linguistic structure, vocabulary and grammatical functions are presented when needed. Therefore the aim of CBI is to 
help students acquire language from the context of learning itself through the application of natural mental perception, analysis, and integration skills (Baby, 2018).

By providing the challenging content and task CBI can increase the self-esteem of students and improve their critical thinking skills (Karim and Rahman, 2016). Its diverse prototype models that fit the context in which it is applied, CBI provides flexible model of language teaching(Duenas, 2004) It is also a holistic language teaching approach that can be positioned as a system of methodologies, philosophical orientations, syllabus designs and teaching frameworks ( Stryker and Leaver, 1997 cited in Duenas, 2004).

In CBI, language teaching should not be separated from the context in which it is taught, and the curriculum developed based on the content to be taught, not on the structure of language (Erickson \& Schulz, 1981 cited in Freiermuth, 2001). The language teaching model that is integrated with teaching content provides opportunities for second language learners to improve their ability to produce discourse related to the theme of the content they are learning. In addition, students will also be proficient in analyzing tasks related to the content being taught, such as creative mathematical calculations, experimental tasks in the laboratory, and historical investigations. Students can also develop problem solving skills and collaborate through the use of appropriate academic languages (Arieh Sherris, 2008).

Teachers who use the CBI approach use social or science study content as a means of developing second language vocabulary, grammar structure, and academic skills(Sasser, 2003) However, the focus of CBI language teaching is not on the rules of grammatical language nor on teaching vocabularies but on the topic or theme of the content presented. The simultaneous interaction of content and language teaching can provide a good learning environment for language learners (Sar1 et al., 2015).

\section{METHODOLOGY}

\section{Setting and Subject of the Research}

This research was carried out at a private university in Kendari, Indonesa. As the researcher stated in the background, one of the problems in teaching reading at Islamic Education Department at the university was the unavailability of reading instructional materials compiled based on student needs analysis. Therefore, as an English language lecturer, the researcher was interested in providing solutions by conducting research related to content- based reading instructional material design for the department. The research subject was second semester students of the Islamic Education Department.

\section{Instrument of the Research}

In this study, there are two research instruments were used, namely questionnaire and interview. The questionnaire was used to obtain data relating to students' perception toward the integrated content based reading instructional material designed by the researcher. The students' need in learning reading, including the topics they needed in reading learning related to Islamic material. The questionnaire was also needed to obtain data related to students' learning need, students' personal information, and students' reading existing knowledge.

In addition to the questionnaire, the researchers also used interview instruments. Interview was used to obtain data from students and lecturers related to what things were needed by the students in reading learning, topics that must be included in reading material, and also about learning strategies the students need.

\section{Procedures of Collecting the Data}

The questionnaire that had been designed by the researchers was given to the students after previously asking for approval from the respondent. Related to the interview, the researcher firstly asked for the willingness of the students and lecturers to be interviewed, both related to the time and place of the interview, this is necessary so that the atmosphere of the interview runs comfortably.

\section{Techniques of Data Analysis}

The data obtained from the questionnaire using a Likert scale were analyzed based on predetermined categories, namely the proficiency level, the important level, frequency level, and agreement level, with the score range from one to four (1-4) for each category. Then the data were analyzed by calculating the average score and the percentage of each category by using the percentage and the average score formula:

a. The formula used to calculate the mean score:

$$
\mathrm{M}=\frac{\sum f x}{\mathrm{~N}}
$$


Where:

$$
\begin{array}{ll}
\mathrm{M} & : \text { Mean } \\
\mathrm{f} & : \text { Frequency } \\
\mathrm{N} & : \text { The number of respondents/questions } \\
\sum \mathrm{fx} & : \text { The sum of scores }
\end{array}
$$

b. The formula used to calculate percentages

$$
\mathrm{P}=\mathrm{f} / \mathrm{N} \times 100 \%
$$

Where:

$$
\begin{array}{ll}
\mathrm{P} & : \text { Percentage } \\
\mathrm{F} & : \text { Frequency } \\
\mathrm{N} & \text { : Total of respondents/ questions }
\end{array}
$$

Data obtained from interviews with respondents will be analyzed using a qualitative analysis approach based on the method formulated by Miles and Huberman (1994), namely data reduction, data display, and making conclusion.

\section{RESULT AND DISCUSSION}

After the content-based reading instructional material was implemented, the researchers then distributed questionnaires to the students and the English teachers of Islamic Education department to find out their perceptions regarding the content-based reading instructional materials.

The data related to the students' perceptions toward the content- based reading instructional material is presented in the tables below.

Table 1:. The students' perception toward the usefulness of the content-based reading instructional material in improving the students' insight about Islamic knowledge and English language skill.

\begin{tabular}{|l|l|c|l|l|}
\hline Scales & Score $(\mathrm{X})$ & Total of respondents & fx & Percentage \\
\hline Very Agree & 4 & 12 & 48 & $66.6 \%$ \\
\hline Agree & 3 & 6 & 18 & $33.3 \%$ \\
\hline Disagree & 2 & - & - & - \\
\hline Very Disagree & 1 & - & - & - \\
\hline Sum score & 18 & 66 & $100 \%$ \\
\hline Mean Score $=66 / 18=3.66$ &
\end{tabular}

Table 1 above shows the students' perceptions related to the usefulness of the content-based reading instructional material in enhancing the students' insight about Islamic knowledge as well as English language skills. Table 1 shows that from 18 respondents who gave answers, 12 respondents stated very agree and 6 respondents stated agree, based on the calculation of the mean score, the score 3.66 was obtained, and the score was at the level of 3.28-4.03. Thus the researcher can conclude that students have very positive perceptions about the usefulness of the content-based instructional material in increasing students' insights about Islamic knowledge and English language skill. 
Table 2: The students' perception toward the usefulness of the content-based reading instructional material in creating the pleasant learning atmosphere.

\begin{tabular}{|l|l|l|l|l|}
\hline Scales & Score (X) & $\begin{array}{c}\text { Total of } \\
\text { respondents (f) }\end{array}$ & fx & Percentage \\
\hline Very Agree & 4 & 3 & 14 & $16.6 \%$ \\
\hline Agree & 3 & 15 & 45 & $83.3 \%$ \\
\hline Disagree & 2 & - & - & - \\
\hline Very Disagree & 1 & - & - & - \\
\hline Sum score & 18 & 59 & $100 \%$ \\
\hline Mean Score $=59 / 18=3.27$ &
\end{tabular}

Table 2. above shows the students' perceptions related to the usefulness of the content-based reading instructional material in creating the pleasant learning atmosphere. Table 2 shows that from 18 respondents who gave answers, 3 respondents stated very agree and 15 respondents stated agree, based on the calculation of the mean score, the score 3.27 was obtained, and the score was at the level of 2.52-3.27. Thus the researcher can conclude that students have very positive perceptions about the usefulness of the content-based instructional material in creating the pleasant learning atmosphere.

Table 3: The students' perception toward the usefulness of the content-based reading instructional material in increasing the students' motivation in learning English.

\begin{tabular}{|l|l|l|l|l|}
\hline Scale & Score $(\mathrm{X})$ & $\begin{array}{c}\text { Total of } \\
\text { respondent (f) }\end{array}$ & Fx & Percentage \\
\hline Very Agree & 4 & 2 & 8 & $11.1 \%$ \\
\hline Agree & 3 & 16 & 48 & $88.8 \%$ \\
\hline Disagree & 2 & - & - & - \\
\hline Very Disagree & 1 & - & - & - \\
\hline Sum score & 18 & 56 & $100 \%$ \\
\hline Mean Score $=56 / 18=3.11$ &
\end{tabular}

Table 3: above shows the students' perceptions related to the usefulness of the content-based reading instructional material in increasing the students' motivation in learning English. Table 3 shows that from 18 respondents who gave answers, 2 respondents stated very agree and 16 respondents stated agree, based on the calculation of the mean score, the score 3.11 was obtained, and the score was at the level of 2.52-3.27. Thus the researcher can conclude that students have very positive perceptions about the usefulness of the content-based instructional material in increasing the students' motivation in learning English.

Table 4: The students' perception toward the usefulness of the material in creating a relaxed atmosphere of learning.

\begin{tabular}{|l|l|l|l|l|}
\hline Scale & Score $(\mathrm{X})$ & $\begin{array}{c}\text { Total of } \\
\text { respondent (f) }\end{array}$ & Fx & Percentage \\
\hline Very Agree & 4 & 5 & 20 & $27.7 \%$ \\
\hline Agree & 3 & 12 & 36 & $66.6 \%$ \\
\hline Disagree & 2 & 1 & 2 & $5.5 \%$ \\
\hline Very Disagree & 1 & - & - & - \\
\hline Sum score & 18 & 58 & $100 \%$ \\
\hline Mean Score $=58 / 18=3.22$ &
\end{tabular}

Table 4 above shows the students' perceptions related to the usefulness of the content-based reading instructional material in creating a relaxed atmosphere of learning. Table 4 shows that from 18 respondents who gave answers, 5 respondents stated very agree, 12 respondents stated agree, and 1 respondent stated disagree. Based on the calculation of the mean score, the score 3.22 was obtained, and the score was at the level of 2.52-3.27. Thus the researcher can conclude that students have very positive perceptions about the usefulness of the content-based instructional material in creating a relaxed atmosphere of learning. 
Table 5: The students' perception toward the suitability of the material with the needs of the students of Islamic education department.

\begin{tabular}{|l|l|c|c|c|}
\hline Scale & Score (X) & $\begin{array}{c}\text { Total of } \\
\text { respondent (f) }\end{array}$ & Fx & Percentage \\
\hline Very Agree & 4 & 5 & 20 & $27.7 \%$ \\
\hline Agree & 3 & 13 & 39 & $72.2 \%$ \\
\hline Disagree & 2 & - & - & - \\
\hline Very Disagree & 1 & - & - & $100 \%$ \\
\hline Sum score & 18 & 59 & \\
\hline Mean Score $=59 / 18=3.27$ &
\end{tabular}

Table 5 above shows the students' perceptions toward the suitability of the material with the needs of the students of Islamic education department. Table 5 shows that from 18 respondents who gave answers, 5 respondents stated very agree and 13 respondents stated agree, based on the calculation of the mean score, the score 3.27 was obtained, and the score was at the level of 2.52-3.27. Thus the researcher can conclude that students have very positive perceptions toward the suitability of the material with the needs of the students of Islamic education department.

Table 6 The students' perception toward the relevant of the material with the daily lives of the Islamic department students.

\begin{tabular}{|l|c|c|c|c|}
\hline Scale & Score (X) & $\begin{array}{c}\text { Total of } \\
\text { respondent (f) }\end{array}$ & Fx & Percentage \\
\hline Very Agree & 4 & 6 & 24 & $33.3 \%$ \\
\hline Agree & 3 & 11 & 33 & $61.1 \%$ \\
\hline Disagree & 2 & 1 & 2 & $5.5 \%$ \\
\hline Very Disagree & 1 & - & - & - \\
\hline Sum score & 18 & 59 & $100 \%$ \\
\hline Mean Score $=59 / 18=3.27$
\end{tabular}

Table 6 above shows the students' perceptions toward the relevant of the material with the daily lives of the Islamic department students. Table 6 shows that from 18 respondents who gave answers, 6 respondents stated very agree, 11 respondents stated agree, and 1 respondent stated disagree. Based on the calculation of the mean score, the score 3.27 was obtained, and the score was at the level of 2.52-3.27. Thus the researcher can conclude that students have very positive perceptions toward the relevant of the material with the daily lives of the Islamic department students.

Table 7 The students' perception toward the usefulness of the content- based reading instructional material to facilitate the students in understanding the material easily.

\begin{tabular}{|l|l|c|c|c|}
\hline Scale & Score $(\mathrm{X})$ & $\begin{array}{c}\text { Total of } \\
\text { respondent (f) }\end{array}$ & Fx & Percentage \\
\hline Very Agree & 4 & 5 & 20 & $27.7 \%$ \\
\hline Agree & 3 & 13 & 39 & $72.2 \%$ \\
\hline Disagree & 2 & - & - & - \\
\hline Very Disagree & 1 & - & - & $100 \%$ \\
\hline Sum score & 18 & 59 & \\
\hline Mean Score $=59 / 18=3.27$ &
\end{tabular}

Table 7 above shows the students' perceptions toward the usefulness of the content- based reading instructional material to facilitate the students in understanding the material easily. Table 7 . shows that from 18 respondents who gave answers, 5 respondents stated very agree and 13 respondents stated agree, based on the calculation of the mean score, the score 3.27 was obtained, and the score was at the level of 2.52-3.27. Thus the researcher can conclude that students have very positive perceptions toward the usefulness of the content- based reading instructional material to facilitate the students in understanding the material easily. 
Table 8 The students' perception toward the usefulness of the content- based reading instructional material to increase students' confidence in learning English.

\begin{tabular}{|l|l|l|l|l|}
\hline Scale & Score (X) & $\begin{array}{c}\text { Total of } \\
\text { respondent (f) }\end{array}$ & Fx & Percentage \\
\hline Very Agree & 4 & 6 & 24 & $33.3 \%$ \\
\hline Agree & 3 & 11 & 33 & $61.1 \%$ \\
\hline Disagree & 2 & 1 & 2 & $5.5 \%$ \\
\hline Very Disagree & 1 & - & - & - \\
\hline Sum score & 18 & 59 & $100 \%$ \\
\hline Mean Score $=59 / 18=3.27$ &
\end{tabular}

Table 8 above shows the students' perceptions toward the usefulness of the content- based reading instructional material to increase students' confidence in learning English. Table 8 shows that from 18 respondents who gave answers, 6 respondents stated very agree, 11 respondents stated agree, and 1 respondent stated disagree. Based on the calculation of the mean score, the score 3.27 was obtained, and the score was at the level of 2.52-3.27. Thus the researcher can conclude that students have very positive perceptions toward the usefulness of the content- based reading instructional material to increase students' confidence in learning English.

Table 9 The students' perception toward the usefulness of the content- based reading instructional material in improving students' English skills.

\begin{tabular}{|l|l|l|l|l|}
\hline Scale & Score $(\mathrm{X})$ & $\begin{array}{c}\text { Total } \\
\text { respondent (f) }\end{array}$ & Fx & Percentage \\
\hline Very Agree & 4 & 6 & 24 & $33.3 \%$ \\
\hline Agree & 3 & 11 & 33 & $61.1 \%$ \\
\hline Disagree & 2 & 1 & 2 & $5.5 \%$ \\
\hline Very Disagree & 1 & - & - & - \\
\hline Sum score & 18 & 59 & $100 \%$ \\
\hline \multicolumn{2}{l|}{} \\
\hline
\end{tabular}

Table 9 above shows the students' perceptions toward the usefulness of the content- based reading instructional material in improving students' English skills.Table 9. shows that from 18 respondents who gave answers, 6 respondents stated very agree, 11 respondents stated agree, and 1 respondent stated disagree. Based on the calculation of the mean score, the score 3.27 was obtained, and the score was at the level of 2.52-3.27. Thus the researcher can conclude that students have very positive perceptions toward the usefulness of the content- based reading instructional material in improving students' English skills.

Table 10 The students' perception toward the usefulness of the content- based reading instructional material in increasing the students' enthusiasm in learning.

\begin{tabular}{|l|c|c|c|c|}
\hline Scale & Score $(\mathrm{X})$ & $\begin{array}{c}\text { Total of } \\
\text { respondent (f) }\end{array}$ & Fx & Percentage \\
\hline Very Agree & 4 & 7 & 28 & $38.8 \%$ \\
\hline Agree & 3 & 10 & 30 & $55.5 \%$ \\
\hline Disagree & 2 & 1 & 2 & $5.5 \%$ \\
\hline Very Disagree & 1 & - & - & - \\
\hline Sum score & 18 & 60 & $100 \%$ \\
\hline Mean Score $=60 / 18=3.33$ &
\end{tabular}

Table 10 above shows the students' perceptions toward the usefulness of the content- based reading instructional material in increasing the students' enthusiasm in learning. Table 10 shows that from 18 respondents who gave answers, 7 respondents stated very agree, 10 respondents stated agree, and 1 respondent stated disagree. Based on the calculation of the mean score, the score 3.33 was obtained, and the score was at the level of 2.52-3.27. Thus the researcher can conclude that students have very positive perceptions toward the usefulness of the content- based reading instructional material in increasing the students' enthusiasm in learning. 
Table 11: The students' perception toward the suitability of content-based reading instructional material with the students' learning style.

\begin{tabular}{|l|l|l|l|l|}
\hline Scale & Score (X) & $\begin{array}{c}\text { Total of } \\
\text { respondent (f) }\end{array}$ & Fx & Percentage \\
\hline Very Agree & 4 & 6 & 24 & $33.3 \%$ \\
\hline Agree & 3 & 10 & 30 & $55.5 \%$ \\
\hline Disagree & 2 & 2 & 4 & $11.1 \%$ \\
\hline Very Disagree & 1 & - & - & - \\
\hline Sum score & 18 & 58 & $100 \%$ \\
\hline Mean Score $=58 / 18=3.22$ &
\end{tabular}

Table 11 above shows the students' perceptions toward the suitability of content-based reading instructional material with the students' learning style. Table 11 shows that from 18 respondents who gave answers, 6 respondents stated very agree, 11 respondents stated agree, and 2 respondent stated disagree. Based on the calculation of the mean score, the score 3.22 was obtained, and the score was at the level of 2.52-3.27. Thus the researcher can conclude that students have very positive perceptions toward the suitability of content-based reading instructional material with the students' learning style.

The conclusion regarding the students' perceptions toward the content-based reading instructional material is presented in the following table.

Table. 12: The students' perception toward content-based reading instructional material.

\begin{tabular}{|c|c|c|c|}
\hline NO & Statement & Average & Category \\
\hline 1 & $\begin{array}{l}\text { The students' perception toward the usefulness of the content- } \\
\text { based reading instructional material in improving the students' insight } \\
\text { about Islamic knowledge and English language skill. }\end{array}$ & 3.66 & $\begin{array}{l}\text { Very } \\
\text { Positive }\end{array}$ \\
\hline 2 & $\begin{array}{l}\text { The students' perception toward the usefulness of the content- } \\
\text { based reading instructional material in creating the pleasant learning } \\
\text { atmosphere. }\end{array}$ & 3.27 & Positive \\
\hline 3 & $\begin{array}{l}\text { The students' perception toward the usefulness of the content- } \\
\text { based reading instructional material in increasing the students' } \\
\text { motivation in learning English. }\end{array}$ & 3.11 & Positive \\
\hline 4 & $\begin{array}{l}\text { The students' perception toward the usefulness of the material in } \\
\text { creating a relaxed atmosphere of learning. }\end{array}$ & 3.22 & Positive \\
\hline 5 & $\begin{array}{l}\text { The students' perception toward the suitability of the material with } \\
\text { the needs of the students of Islamic education department. }\end{array}$ & 3.27 & Positive \\
\hline 6 & $\begin{array}{l}\text { The students' perception toward the relevant of the material with } \\
\text { the daily lives of the Islamic department students. }\end{array}$ & 3.27 & Positive \\
\hline 7 & $\begin{array}{l}\text { The students' perception toward the usefulness of the content- } \\
\text { based reading instructional material to facilitate the students in } \\
\text { understanding the material easily. }\end{array}$ & 3.27 & Positive \\
\hline 8 & $\begin{array}{l}\text { The students' perception toward the usefulness of the content- } \\
\text { based reading instructional material to increase students' confidence in } \\
\text { learning English. }\end{array}$ & 3.27 & Positive \\
\hline 9 & $\begin{array}{l}\text { The students' perception toward the usefulness of the content- } \\
\text { based reading instructional material in improving students' English } \\
\text { skills. }\end{array}$ & 3.27 & Positive \\
\hline 10 & $\begin{array}{l}\text { The students' perception toward the usefulness of the content- } \\
\text { based reading instructional material in increasing the students' }\end{array}$ & 3.33 & Very \\
\hline
\end{tabular}




\begin{tabular}{|c|l|c|c|}
\hline & enthusiasm in learning. & Positive \\
\hline 11 & $\begin{array}{c}\text { The students' perception toward the suitability of content-based } \\
\text { reading instructional material with the students' learning style. }\end{array}$ & 3.22 & Positive \\
\hline \multicolumn{2}{|l|}{ Mean score } & 3.28 & $\begin{array}{c}\text { Very } \\
\text { Positive }\end{array}$ \\
\hline
\end{tabular}

Table 12 above shows that the average score of students' perception toward content based instructional reading material is 3.28. The score was at the level 3.28-4.03. Based on the accumulation of the average score, the researcher can conclude that students of Islamic education department have a very positive perception toward the Content-Based Reading Instructional Material.

By providing challenging content and task, CBI can increase the self-esteem of students and improve their critical thinking skills (Karim and Rahman, 2016). With its diverse prototype models that fit the context in which it is applied, CBI provides a flexible model of language teaching(Duenas, 2004). It is also a holistic language teaching approach that can be positioned as a system of methodologies, philosophical orientations, syllabus designs, and teaching frameworks ( Stryker and Leaver, 1997 cited in Duenas, 2004).

In CBI, language teaching should not be separated from the context in which it is taught, and the curriculum developed based on the content to be taught, not on the structure of language (Erickson \& Schulz, 1981 cited in Freiermuth, 2001). The language teaching model that is integrated with teaching content provides opportunities for second language learners to improve their ability to produce discourse related to the theme of the content they are learning. In addition, students will also be proficient in analyzing tasks related to the content being taught, such as creative mathematical calculations, experimental tasks in the laboratory, and historical investigations. Students can also develop problem-solving skills and collaborate through the use of appropriate academic languages (Arieh Sherris, 2008).

Teachers who use the CBI approach use social or science study content as a means of developing second language vocabulary, grammar structure, and academic skills(Sasser, 2003). However, the focus of CBI language teaching is not on the rules of grammatical language nor on teaching vocabularies but on the topic or theme of the content presented. The simultaneous interaction of content and language teaching can provide a good learning environment for language learners (Sar1 et al., 2015)

According to Coyle (2007), CBI has some positive impacts on the students, such as CBI can increase students' linguistic competence, improve the students' skill in problem-solving and risk-taking, improve the skill in vocabulary learning and students' awareness in grammatical aspect. Besides that CBI can improve the students' linguistic confidence, motivate the students to be more motivated and independent (Coyle, 2007 cited in Tarnopolsky, 2013)

In CBI, the content presented has a very significant function and language functions as a means of conveying meaning. Information is presented not in single sentences but in more meaningful forms such as discourse or text. Teaching skills in the target language are integrated so that the class is like an interactive social situation that makes students active in the classroom. Authentic and meaningful content will motivate the EFL learners to make greater connections between topics, elaborations with learning materials, and can recall information better (Jaelani, 2017). Through its two-way bilingual immersion program, the curriculum in this program is taught through the foreign language. some models of integrating language teaching and content instruction in the program are essential (Crandal, 1994 cited in Jalilzadeh \& Tahmasebi, 2014).

By employing authentic reading materials, the students in CBI model are not only expected to be able to understand the information presented in the text but also interpret and evaluate it. CBI approach creates a classroom atmosphere where students can give responses to reading and learning material. It recognizes that academic writing follows listening and reading, and thus requires students to synthesize facts and ideas from multiple sources as preparation for writing. Integration of varied teaching skills within the CBI was emphasized as preparation for students to complete their academic assignments (Stoller, 2002 cited in Jalilzadeh and Tahmasebi, 2014).

\section{CONCLUSION}

Based on the research result presented above, the researchers can conclude that the students have a very positive perception toward the Integrated Content-Based Reading Instructional Material designed by the researcher. Most of the students perceive that the Integrated Content-Based Reading Instructional Material can improve their insight about 
Islamic knowledge and English language skill. It can also create the pleasant learning atmosphere. Furthermore, the instructional material can facilitate the students in understanding the material easily, increase the students' confidence in learning English, and also improve the students' reading skills.

The last, the researchers recommend the teachers or lecturers of English to design instructional material based on need analysis. Instructional material that is suitable with the students' needs will make students motivated to learn. Curriculum and syllabus of English learning at Islamic Universities, especially at the Islamic Education Department of must be adapted to the needs of students.

\section{REFERENCES}

Abdul Karim and Mohammad Mosiur Rahman. (2016). Revisiting the Content-Based Instruction in Language Teaching in relation with CLIL : Implementation and Outcome. International Journal of Applied Linguistics \& English Literature, 5(7). https://doi.org/10.7575/aiac.ijalel.v.5n.7p.254

Aisyah, S. (2017). the Effectiveness of Content-Based Instruction To Teach Speaking Viewed From Students' Creativity. PREMISE JOURNAL:ISSN Online: 2442-482x, ISSN Printed: 2089-3345, 3(1), 83-92. https://doi.org/10.24127/pj.v3i1.701

Arieh Sherris. (2008). Integrated Content and Language Instruction. CAL Digest, September. 11.

Baby, K. T. (2018). Integrating Content Based Instruction in Fondation Programme. Epitome Journals, 1(April), 0-

Bolanos, H. (2013). Strengths and Weaknesses of Content Based Instruction (CBI) in EFL Settings at Beginning Langugae Development Stages (Issue May). University of Narino.

Brinton, D. M., \& Snow, M. A. (2017). The Evolving Architecture of Content-Based Instruction Introduction |||. University of Michigan, $c, 3$.

Butler, Y. G. (2005). Content-Based Instruction in EFL Contexts: Considerations for Effective Implementation Yuko Goto Butler. Jalt Journal, 27(2), 227-245.

Cammarata, L. (2014). Cammarata , L . ( 2010 ). Foreign language teachers 'struggle to learn content-. L2 Journal, 2(December), 89-118.

Duenas. (2004). The Whats, Whys , Hows and Whos of Content-Based Instruction in SecondIForeign Language Education. International Journal of English Studies, 4(1), 73-96.

Dupuy, B. C. (2000). Content-Based Instruction : Can it Help Ease the Tr a n s i t i o $\mathrm{n}$ f rom Beginning to Advanced F o reign Language Classes? Foreign Language Annals, 33(2), 205-223.

Freiermuth, M. R. (2001). Influences of Content-Based Instruction in the ESP Classroom.

Lai and Asornjarung. (2017). The Effects of Content-based Instruction on Listening and Speaking Abilities of The Effects of Content-based Instruction on Listening and Speaking Abilities of Thai EFL University Students. Creative Practices in Language Learning and Teaching (CPLT, November 2017. 134.

Madrid and Sanches. (2001). Content-Based Second Language Teaching. Present and Future Trends in TEFL, 101-

Mustofa Amiri and Azar Hosseini Fatemi. (2014). The Impact of Content-based Instruction on Students ' Achievement in ESP Courses and Their Language Learning Orientation. Theory and Practice in Languge Studies, 4(10), 2157-2167. https://doi.org/10.4304/tpls.4.10.2157-2167

Myriam Met. (1999). Content-Based Instruction: Defining Terms Making Decision. NFLC Reports.

Oxford, R. L. (1993). Progress in Tertiary Content-Based ESL Instruction. TESL Canada Journal, 11(1), 75-97.

Peng, Y. (2017). Content-Based Instruction of EFL and Its Effects on Learners' Needs in China. Education Journal, 6(3), 116-119. https://doi.org/10.11648/j.edu.20170603.12

Sarı, İ., Karata, H., \& Ejder, A. (2015). Students ' Content Responsibility In Content Based Instruction ( cb 1 ) And Active Participation Students ' Content Responsibili ty in Content Based Instruction ( CBI ) and Active Participation. International Online Journal of Education Science, August. https://doi.org/10.15345/iojes.2015.03.012

Sasser, L. (2003). Integrating Language Development and Content-Meeting the Demands of Today's Diverse Classroom. Ideas for Excellence. 
Shabani and Ghasemi. (2014). The Effect of Task-Based Language Teaching ( TBLT ) and Content-Based Language Teaching ( CBLT ) on the Iranian Intermediate ESP Learners' Reading Comprehension. Procedia - Social and Behavioral Sciences, 98, 1713-1721. https://doi.org/10.1016/j.sbspro.2014.03.598

Suraya, F., State, S., Ali, M. A., Anggita, G. M., Kalisa, P., \& State, S. (2018). Merging English into Sport in Aerobic Exercise Based on Content-Based Instruction. LANGUAGE CIRCLE: Journal of Language and Literature, 13(October).

Syaifullah, B. (2014). An evaluation of an esp textbook from lecturers' perspectives: the case of. 07, 237-240.

Tarnopolsky, O. (2013). Content-Based Instruction, CLIL, and Immersion in Teaching ESP at Tertiary Schools in Non-English-Speaking Countries. Joornal of ELT and Applied Linguistic (JELTAL), 1(1), 1-11.

Tsai, Y and Shang. (2010). The Impact of Content-Based Language Instruction on EFL Students 'Reading Performance. 77-85.

Tseng, C. H. (2015). Implementation and Perspectives of A Content-Based Instruction Course in An EFL Context. International Journal of English Language Teaching, 3(8), 1-18.

Villalobos, O. B. (2014). Content-Based Instruction: A Relevant Approach of Language Teaching. Innovaciones Educatives.

Yugandhar, K. (2016). Significance of Material and Ambiance in Content Based Instruction in Improving the Skills of EFL Students. International Journal on Studies in English Language and Literature (IJSELL), 4(5), 35-39. 
Asian Journal of Humanities and Social Studies (ISSN: 2321 - 2799)

Volume 9 - Issue 4, August 2021 